\title{
A new interpretation of the tectonic setting and age of meta-basic volcanics in the Ondor Sum Group, Inner Mongolia
}

\author{
CHU Hang ${ }^{1}$, ZHANG JinRui ${ }^{2}$, WEI ChunJing ${ }^{2 *}$, WANG HuiChu ${ }^{1} \&$ REN YunWei ${ }^{1}$ \\ ${ }^{1}$ Tianjin Institute of Geology and Mineral Resources, Tianjin 300170, China; \\ ${ }^{2}$ School of Earth and Space Sciences, Peking University, Beijing 100871, China
}

Received December 19, 2012; accepted April 8, 2013; published online May 9, 2013

\begin{abstract}
The Ondor Sum Group in the central Inner Mongolia is mainly composed of meta-basic volcanics intercalated with ferruginous quartzite and quartz schist, and has been interpreted as slices of oceanic crust or an ophiolite suite of the Early Paleozoic or much older ages. This paper presents new LA-ICP-MS zircon U-Pb dating and geochemical data for the meta-basic volcanics. The results show that zircons in the meta-basic volcanics were derived from complicated sources, most of which may be captured by basic magma from the country rocks or other sources. They yield a large age range from the Late Archean to Early Mesozoic with the youngest age group between 246 and $261 \mathrm{Ma}$, constraining the protolith of the meta-basic volcanics formed in the Late Permian to Early Triassic. The meta-basic volcanics have an affinity to E-MORB in geochemistry, and also a similarity toward OIB, representing a tectonic setting of limited intra-continental ocean basin. This limited basin might have been related to the continuous extension of the area since the Early Permian and finally closed in the Early Mesozoic.
\end{abstract}

meta-basic volcanics, zircon U-Pb dating, Ondor Sum Group, Central Asian orogen

Citation: $\quad$ Chu H, Zhang J R, Wei C J, et al. A new interpretation of the tectonic setting and age of meta-basic volcanics in the Ondor Sum Group, Inner Mongolia. Chin Sci Bull, 2013, 58: 3580-3587, doi: 10.1007/s11434-013-5862-7

Numerous studies show that the Solonker-Linxi suture zone recorded the termination of convergence of Paleo-Asian Ocean between the Siberia Craton and the North China Craton. But it remains controversial whether the final closure occurred in the Devonian [1-5] or the Late Permian to Early Mesozoic [6-14]. The Ondor Sum Group in the central Inner Mongolia has been regarded as slices of subducted oceanic crust for it is comprised of a large amount of meta-basic volcanics with intercalations of blueschist and ferruginous quartzite. Several scholars established an Early Paleozoic trench-arc-basin system in the central Inner Mongolia combined with the Ordovician island arc, volcanic series in Bainaimiao Group and the Silurian sediments in the Xuniwusu Formation (back-arc basin) $[1,2,5,15]$. Others believed that the Ondor Sum Group might be a Neoproterozoic block that was integrated in the Early Paleozoic subduction mélange belt $[16,17]$. However, based on the zircon

*Corresponding author (email: cjwei@pku.edu.cn)
$\mathrm{U}-\mathrm{Pb}$ dating and geochemical data for the meta-basic volcanics, this paper presents a new interpretation of the age and tectonic setting of the Ondor Sum Group, which is of a great significance to reveal the tectonic framework and evolution of the Central Asian Orogen.

\section{Geological background and sample descrip- tions}

The Ondor Sum Group in the central Inner Mongolia (Figure $1(\mathrm{a})$ ) is distributed about $3000 \mathrm{~km}^{2}$, and can be divided into southern and northern zones. The southern zone lies in the Ondor Sum and Tulinkai area, to the south of which exits the Bainaimiao arc complex. The northern zone is located along the Manghete, Erdaojing and Honger (Figure $1(b))$, to the north of which is distributed the Baolidao arcaccretionary complex. Thus, Xiao et al. [8] divided them into the Ondor Sum subduction-accretion complex in the 


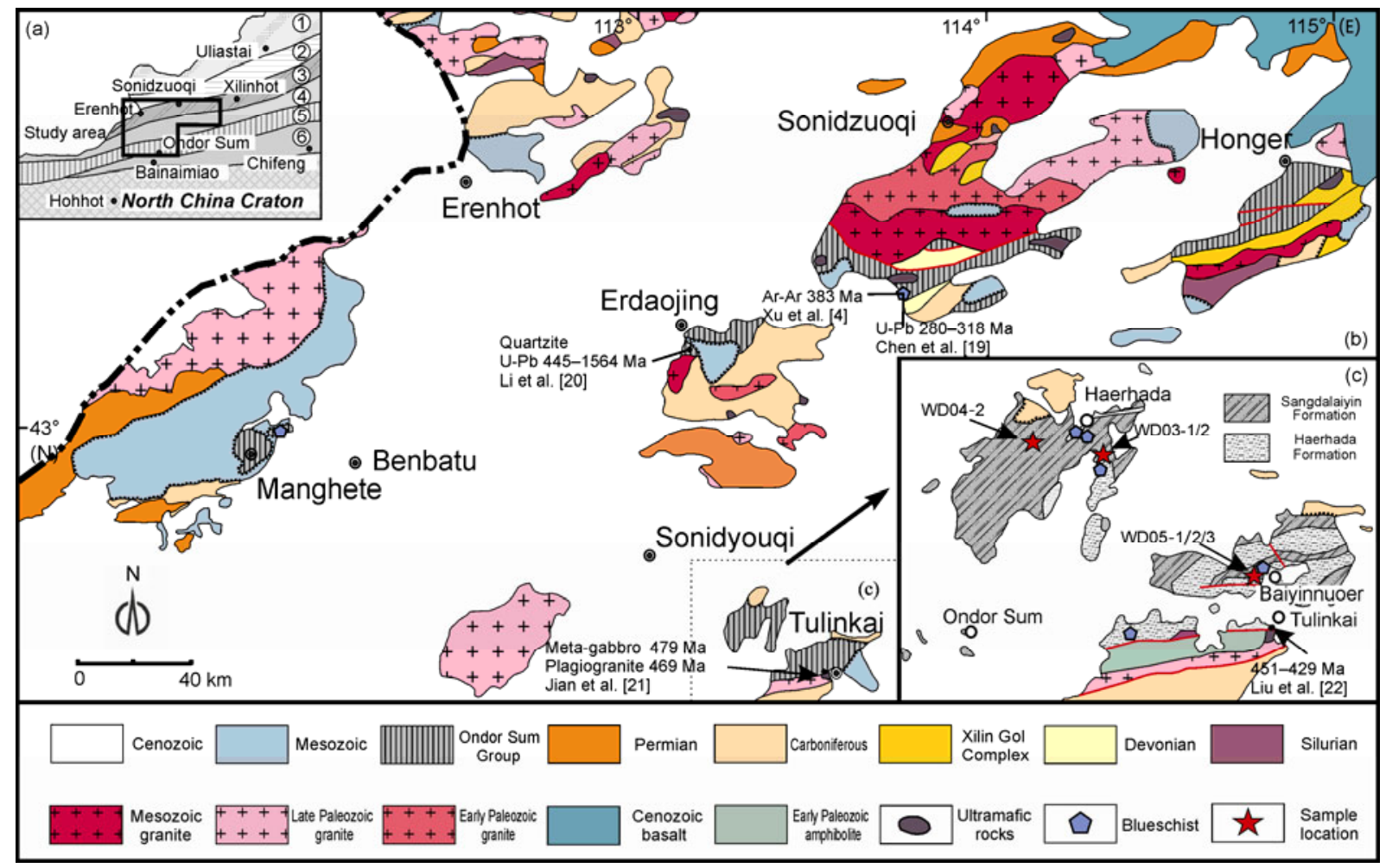

Figure 1 Geological sketch map of central Inner Mongolia showing the distribution of the Ondor Sum Group. (a) Tectonic position of the study area; (b) distribution of the Ondor Sum Group; (c) geological sketch map of the southern zone and sample locations. (1) Southern Mongolian active continental margin; (2) Hegenshan ophiolite-arc-accretion complex; (3) Baolidao arc-accretion complex; (4) Erdaojing accretion complex; (5) Ondor Sum subductionaccretion complex; (6) Bainaimiao arc complex.

south and the Erdaojing accretion complex in the north, while $\mathrm{Xu}$ et al. [5] nominated them, respectively, as the Southern and Northern opposite subduction-orogenic belts. On the distribution area of the Ondor Sum Group are distributed the Late Silurian-Early Devonian Xibiehe Formation, the Devonian Seribayanaobao Formation, the Carboniferous Benbatu and Amushan Formations, the Permian Zhesi Formation and the Xilin Gol complex. The Mesozoic volcano-sedimentary sequences overlie unconformably upon the Paleozoic or older litho-units. Intrusive rocks include the Paleozoic granitic rocks in the Baolidao arc complex [7], Triassic granites [18], Paleozoic amphibolite and plagiogranites.

The Southern zone of Ondor Sum Group is divided into two formations. The lower Sangdalaiyin Formation is mainly composed of meta-basalt and meta-gabbro, intercalated locally with ferruginous quartzite, carbonate and serpentinite. The upper Haerhada Formation mainly includes fine-grained quartzite, chlorite-sericite-quartz schist, ferruginous quartzite and bedded iron ores. In the early 1980's, blueschist was reported in the Sangdalaiyin Formation [23]. All the samples in this study were collected from the Sangdalaiyin Formation (Figure 1(c)). Samples WD03-1/2 are meta- pillow basalts that are less foliated (Figure 2(a)) and show blastoporphyritic texture with augite pseudomorphs consisting of actinolite, epidote, chlorite, carbonate and a minor amount of glaucophane. The matrix is mainly composed of tabular-prismatic plagioclase grains with interstitial chlorite, actinolite and epidote. A few rounded aggregates of carbonate and quartz are present, being original amygdaloids. Samples WD04-2 and WD05-1/2/3 are strongly foliated meta-basalt or chlorite-actinolite phyllite that shows phyllitic structure and lepido-granoblastic texture, and is composed of albite, epidote, actinolite, and a few stilpnomelanes. Albite and epidote commonly occur as lenticular aggregates oriented along the foliation (Figure 2(b)).

\section{Geochemistry}

Major and trace elements of the samples in this study were analyzed by X-ray Fluorescence (XRF) and ICP-MS in laboratory of Tianjin Institute of Geology and Mineral Resources and are presented in Table 1. After ignition loss correction, the rocks show $\mathrm{SiO}_{2}=49.02 \%-52.62 \%$, and are relatively rich-in $\mathrm{TiO}_{2}$ and poor-in $\mathrm{K}_{2} \mathrm{O}$ with $\mathrm{TiO}_{2}=1.27 \%-$ $1.96 \%, \mathrm{Na}_{2} \mathrm{O} / \mathrm{K}_{2} \mathrm{O}=6.89-454.25$ and $\mathrm{Mg}^{\#}=0.44-0.60$. They are plotted in the subalkaline and alkaline basalt fields in $\mathrm{Zr} / \mathrm{TiO}_{2} \times 10^{-4}-\mathrm{Nb} / \mathrm{Y}$ diagram [24] (Figure 3(a)) and show the characteristics of MORB with a trend towards to OIB in $\langle\mathrm{FeO}\rangle / \mathrm{MgO}-\mathrm{TiO}_{2}$ diagram [25] (Figure 3(b)). 

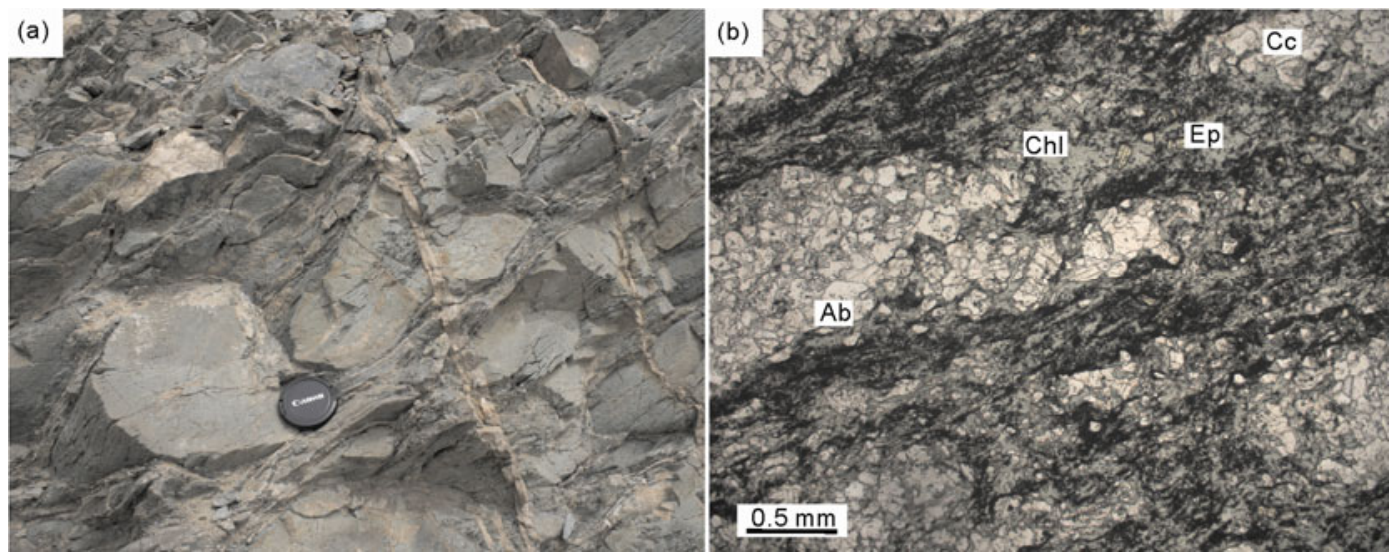

Figure 2 Pillow structure (a) and micro-fabric (b) of meta-basic volcanics in the Ondor Sum Group. Ab, Albite; Chl, chlorite; Ep, epidote; Cc, calcite.

Table 1 Major (\%) and trace element (ppm) data of meta-basic volcanics in the Ondor Sum Group

\begin{tabular}{|c|c|c|c|c|c|c|}
\hline Sample No. & WD03-1 & WD03-2 & WD04-2 & WD05-1 & WD05-2 & WD05-3 \\
\hline $\mathrm{SiO}_{2}$ & 41.91 & 38.04 & 44.04 & 48.07 & 46.24 & 47.86 \\
\hline $\mathrm{TiO}_{2}$ & 1.27 & 1.73 & 1.60 & 1.96 & 1.85 & 1.68 \\
\hline $\mathrm{Al}_{2} \mathrm{O}_{3}$ & 14.97 & 13.97 & 13.95 & 14.32 & 14.64 & 13.74 \\
\hline $\mathrm{Fe}_{2} \mathrm{O}_{3}$ & 3.84 & 1.40 & 2.02 & 5.61 & 6.22 & 6.77 \\
\hline $\mathrm{FeO}$ & 5.18 & 6.73 & 6.58 & 8.82 & 8.62 & 7.40 \\
\hline $\mathrm{MnO}$ & 0.14 & 0.13 & 0.32 & 0.19 & 0.20 & 0.19 \\
\hline $\mathrm{MgO}$ & 6.05 & 5.25 & 7.00 & 6.60 & 6.39 & 6.33 \\
\hline $\mathrm{CaO}$ & 11.19 & 13.45 & 9.16 & 6.06 & 7.49 & 9.23 \\
\hline $\mathrm{Na}_{2} \mathrm{O}$ & 4.20 & 3.26 & 3.63 & 3.27 & 2.99 & 2.49 \\
\hline $\mathrm{K}_{2} \mathrm{O}$ & 0.02 & 0.473 & 0.01 & 0.03 & 0.03 & 0.03 \\
\hline $\mathrm{P}_{2} \mathrm{O}_{5}$ & 0.16 & 0.28 & 0.24 & 0.17 & 0.15 & 0.17 \\
\hline $\mathrm{LOI}\left(\mathrm{CO}_{2}\right)$ & 4.65 & 6.88 & 3.82 & 0.13 & 0.37 & 0.12 \\
\hline LOI & 10.51 & 14.53 & 10.71 & 3.94 & 4.23 & 3.30 \\
\hline Total & 99.42 & 99.25 & 99.27 & 99.02 & 99.04 & 99.19 \\
\hline $\mathrm{Pb}$ & 0.95 & 1.74 & 7.41 & 1.60 & 1.56 & 1.55 \\
\hline $\mathrm{Cr}$ & 454 & 191 & 439 & 42.2 & 93.4 & 80.4 \\
\hline $\mathrm{Ni}$ & 262 & 136 & 190 & 37.8 & 40.3 & 35.0 \\
\hline Co & 55.7 & 46.5 & 45.1 & 47.5 & 40.0 & 38.0 \\
\hline $\mathrm{Rb}$ & 2.03 & 9.36 & 0.72 & 0.85 & 1.28 & 1.38 \\
\hline $\mathrm{Sr}$ & 149 & 182 & 123 & 150 & 181 & 284 \\
\hline $\mathrm{Ba}$ & 22.4 & 33.6 & 13.1 & 18.9 & 16.1 & 16.2 \\
\hline $\mathrm{Nb}$ & 8.23 & 17.6 & 18.7 & 6.21 & 5.53 & 6.14 \\
\hline $\mathrm{Ta}$ & 0.54 & 1.18 & 1.22 & 0.42 & 0.36 & 0.40 \\
\hline $\mathrm{Zr}$ & 86.4 & 133 & 110 & 117 & 102 & 114 \\
\hline $\mathrm{Hf}$ & 2.54 & 3.69 & 3.14 & 3.66 & 3.25 & 3.61 \\
\hline $\mathrm{Ga}$ & 13.0 & 13.0 & 14.7 & 20.3 & 20.4 & 20.0 \\
\hline $\mathrm{U}$ & 1.47 & 1.25 & 1.87 & 0.68 & 0.42 & 0.34 \\
\hline Th & 0.69 & 1.57 & 1.48 & 0.46 & 0.38 & 0.46 \\
\hline $\mathrm{La}$ & 8.48 & 13.5 & 12.5 & 6.23 & 5.45 & 6.37 \\
\hline $\mathrm{Ce}$ & 17.7 & 27.6 & 25.7 & 15.9 & 13.9 & 16.2 \\
\hline $\operatorname{Pr}$ & 2.76 & 4.50 & 3.84 & 2.86 & 2.55 & 2.95 \\
\hline $\mathrm{Nd}$ & 11.8 & 19.0 & 16.0 & 13.9 & 12.5 & 14.3 \\
\hline Sm & 2.91 & 4.29 & 3.83 & 4.23 & 3.81 & 4.31 \\
\hline $\mathrm{Eu}$ & 1.08 & 1.51 & 1.40 & 1.56 & 1.48 & 1.56 \\
\hline $\mathrm{Gd}$ & 3.11 & 4.40 & 4.15 & 5.03 & 4.61 & 5.15 \\
\hline $\mathrm{Tb}$ & 0.57 & 0.69 & 0.70 & 0.97 & 0.89 & 0.98 \\
\hline Dy & 3.76 & 4.12 & 4.32 & 6.53 & 5.98 & 6.62 \\
\hline Но & 0.77 & 0.80 & 0.83 & 1.34 & 1.22 & 1.36 \\
\hline $\mathrm{Er}$ & 2.25 & 2.26 & 2.34 & 3.95 & 3.58 & 3.95 \\
\hline $\mathrm{Tm}$ & 0.38 & 0.36 & 0.37 & 0.67 & 0.60 & 0.67 \\
\hline $\mathrm{Yb}$ & 2.69 & 2.59 & 2.60 & 4.80 & 4.31 & 4.76 \\
\hline $\mathrm{Lu}$ & 0.40 & 0.38 & 0.38 & 0.72 & 0.64 & 0.70 \\
\hline Y & 18.0 & 20.0 & 20.7 & 33.7 & 31.1 & 35.0 \\
\hline$\sum$ REE & 58.66 & 86.00 & 78.96 & 68.69 & 61.52 & 69.88 \\
\hline LREE/HREE & 3.21 & 4.51 & 4.03 & 1.86 & 1.82 & 1.89 \\
\hline$\delta \mathrm{Eu}$ & 1.09 & 1.05 & 1.07 & 1.03 & 1.08 & 1.01 \\
\hline
\end{tabular}


The primitive mantle (PM)-normalized spider diagram (Figure 4(a)) shows that all the samples have higher trace element contents than the primitive mantle. The element distribution patterns mostly exhibit nearly flat but some are right-dipping with a gentle enrichment in light rare earth elements (LREE). A few samples are strongly depleted in large ion lithophile elements (LILE), especially $\mathrm{Rb}$ and $\mathrm{K}$, probably related to the metamorphism and alteration that the rocks have experienced. However, the high field strength elements (HFSE) and rare earth elements (REE) may reflect the protolith geochemical characteristics. The total abundances of REE in the samples are 58.66-86.00 ppm, with $\mathrm{LREE} / \mathrm{HREE}=1.82-4.51$ and without obvious Eu anomaly. The characteristics of HFSE and REE are similar to E-MORB with an evolution trend toward OIB. The samples are plotted in the fields of within-plate basalt and MORB in Hf-Th-Nb/16 diagram [27] (Figure 4(b)) and Ti/100-Zr-Y*3 diagram [28] (Figure 4(c)).

\section{LA-ICP-MS zircon U-Pb dating}

Four samples were elected for LA-ICP-MS zircon U-Pb dating. Similar to making the SHRIMP dating sample, rep- resentative zircons were mounted in an epoxy resin disc, and then polished and coated with gold film. The zircon Cathodoluminesence (CL) imaging was performed in Beijing Navigation technology Ltd. The sample mounts were used later for LA-ICP-MS U-Pb isotope analyses at the State Key Laboratory of Geological Processes and Mineral Resources, China University of Geosciences (Beijing). ${ }^{207} \mathrm{~Pb} /{ }^{206} \mathrm{~Pb}$ and ${ }^{206} \mathrm{~Pb} /{ }^{238} \mathrm{U}$ ratios were calculated using the GLITTER 4.4 program, and then corrected using the Harvard zircon 91500 as external standard. Correction for the common $\mathrm{Pb}$ contribution was made using the measured ${ }^{204} \mathrm{~Pb}$ amount [30]. The weighted average data of the zircon age and Concordia plots were made using ISOPLOT 3.23 programme [31].

Two groups of zircons can be identified from the CL images in Figure 5: Group 1 is the euhedral to subhedral short or long prisms that display closely-spaced concentric oscillatory zoning, and Group 2 is the rounded grains without the clear oscillatory zoning. The zircon $\mathrm{U}-\mathrm{Pb}$ dating results are plotted in Figure 6.

In sample WD03-1, 28 zircon grains were analyzed and 27 of them yield concordant ages in Figure 6(a),(b). These results are dispersive between 237 and $2611 \mathrm{Ma}$, the youngest age group being 237-263 Ma with $\mathrm{Th} / \mathrm{U}$ ratios ranging
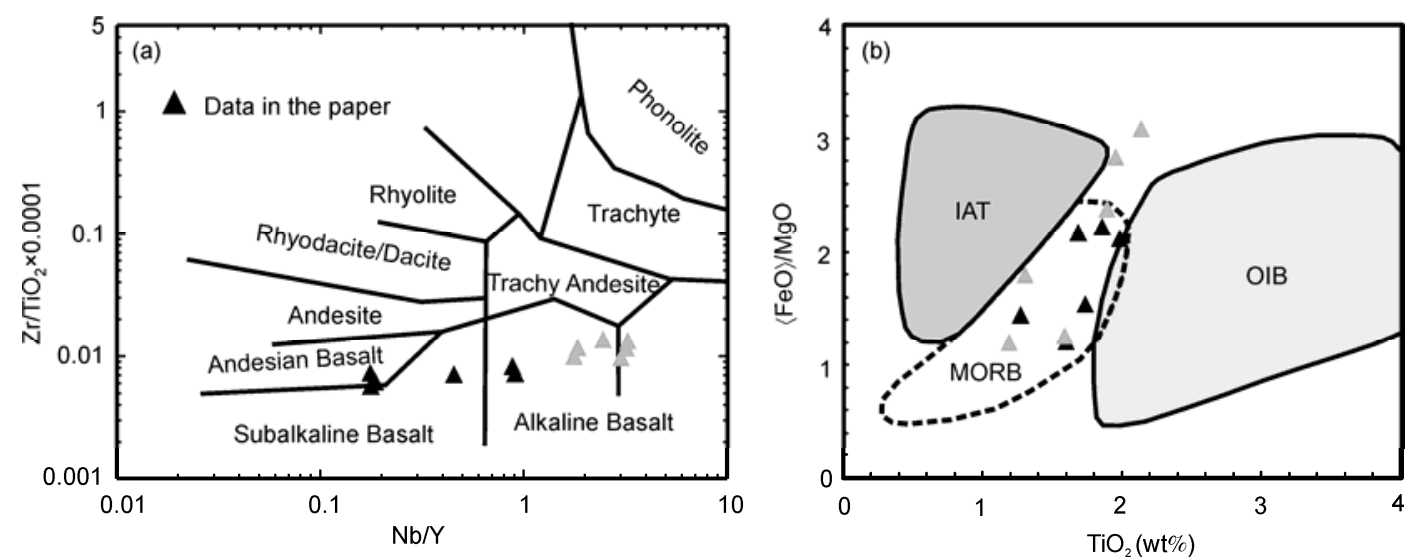

Figure $3 \mathrm{Zr} / \mathrm{TiO}_{2} \times 10^{-4}-\mathrm{Nb} / \mathrm{Y}$ (a) and $\langle\mathrm{FeO}\rangle / \mathrm{MgO}_{-} \mathrm{TiO}_{2}$ (b) diagrams of meta-basic volcanics in the Ondor Sum Group. The grey triangles represent the data cited from [26]. IAT, Island-arc tholeiite; OIB, ocean-island basalt; MORB, mid-ocean ridge basalt.
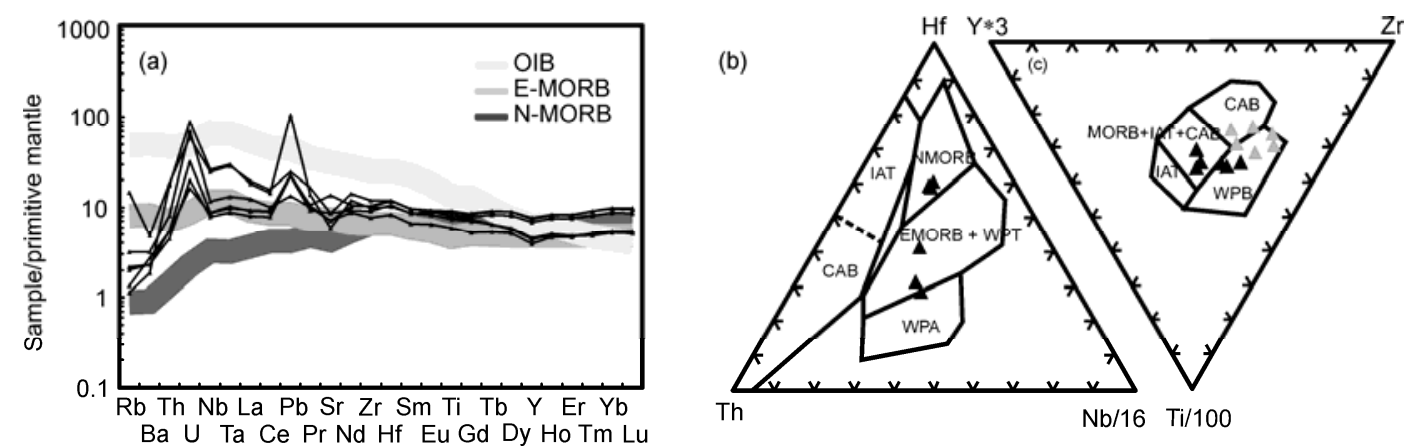

Figure 4 Trace element diagrams of meta-basic volcanics in the Ondor Sum Group. (a) The primitive mantle (PM)-normalized spider diagram where the element contents of primitive mantle, OIB, E-MORB and N-MORB are cited from [29]; (b) Hf-Th-Nb/16 diagram; (c) Ti/100-Zr-Y*3 diagram; E/N-MORB: $\mathrm{E} / \mathrm{N}$ type mid-ocean ridge basalt; CAB, calc-alkali basalt; WPT, within-plate tholeiite; WPA, within-plate alkali basalt; WPB, within-plate basalt. 


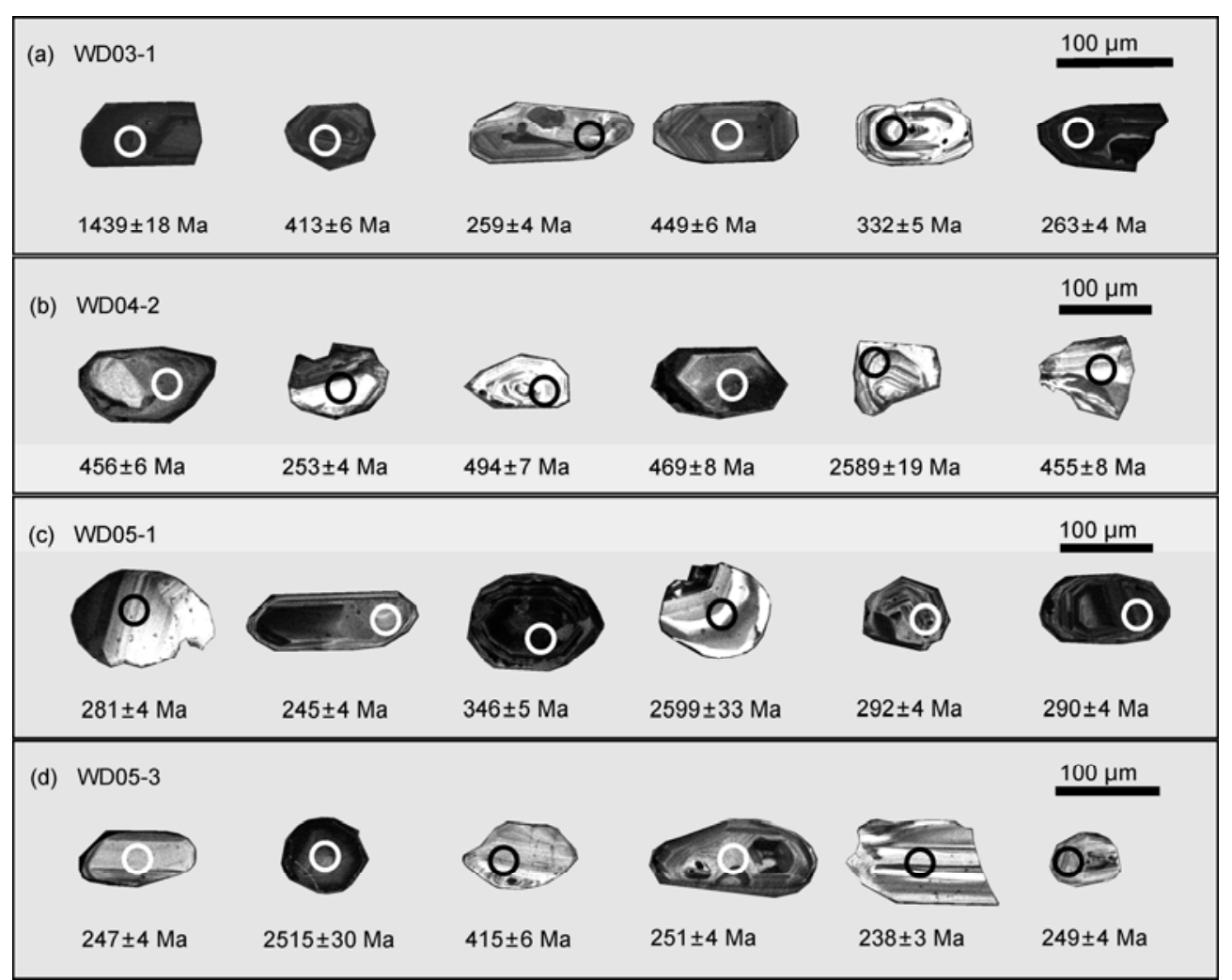

Figure 5 Cathodoluminescence images of zircons from meta-basic volcanics in the Ondor Sum Group.

from 0.26 to 0.96 .

The 40 zircon grains were analyzed in sample WD04-2 and 39 grains yield concordant ages ranging from 253 to $2734 \mathrm{Ma}$ (Figure 6(a),(d)). A cluster involving 25 zircon analyses yields an apparent age peak between 440 and 494 Ma with $\mathrm{Th} / \mathrm{U}$ ratios from 0.29 to 0.89 . There are 4 analyses which give younger ${ }^{206} \mathrm{~Pb} /{ }^{238} \mathrm{U}$ ages from 253 to $306 \mathrm{Ma}$, with $\mathrm{Th} / \mathrm{U}$ ratios between 0.72 and 0.87 .

In sample WD05-1, 25 zircon grains were analyzed and 22 grains give concordant ages ranging from 245 to 2599 Ma (Figure 6(e),(f)). A cluster involving 11 zircon analyses yields ages from 245 to $299 \mathrm{Ma}$, with $\mathrm{Th} / \mathrm{U}$ ratios between 0.49 and 0.81 .

The 24 zircon grains were analyzed in sample WD05-3 and 21 grains yield concordant ages (Figure $6(\mathrm{~g}),(\mathrm{h})$ ), which are grouped into two clusters: $1639-2599 \mathrm{Ma}$ and 238-257 Ma. The younger cluster involves 12 analyses with a weighted mean age of $246 \pm 3 \mathrm{Ma}(\mathrm{MSWD}=1.9)$ and $\mathrm{Th} / \mathrm{U}$ ratios from 0.21 to 0.70 .

\section{Discussion and conclusion}

It has been a controversial issue for the formation age of the Ondor Sum Group. Using whole-rock Sm-Nd and $\mathrm{Rb}-\mathrm{Sr}$ isochrons, $\mathrm{Xu}$ et al. [16] and Zhang and $\mathrm{Wu}$ [17] proposed that the Ondor Sum Group was formed in the Neoproterozoic and later integrated into the Early Paleozoic subduction mélange belt. However, these age results are found to be unreliable because reprocessing the original data using ISOPLOT only gives pseudo-isochrons. Many scholars believed that the Ondor Sum Group represent slices of Early-Paleozoic Oceanic crust and had experienced a blueschist facies metamorphism [3-5,8,15-17,32]. This idea was supported by a few ${ }^{40} \mathrm{Ar} /{ }^{39} \mathrm{Ar}$ plateau age dating results, which, for instance, are $446 \pm 15$ Ma for glaucophane from blueschist [33] and 453.2 $\pm 1.8 \mathrm{Ma}$ and $449.4 \pm 1.8 \mathrm{Ma}$ for phengite from quartzite mylonites [32] in the southern zone of the Ondor Sum group, and $383 \mathrm{Ma}$ for glaucophane from blueschist in the northern zone of the Ondor Sum group [4]. It was noted that Chen et al. [19] dated the same blueschist in the northern zone using zircon U-Pb method and the results suggest that the protolith of the blueschist should be younger than 280-318 Ma, completely different from the $\mathrm{Ar}-\mathrm{Ar}$ ages. Therefore, it requires further interpretation for the significance of the Ar-Ar ages. Based on zircon U-Pb dating results from Ondor Sum Group, Li et al. [20] asserted that meta-andesite from the Sangdalaiyin Formation could be formed at $470 \pm 2 \mathrm{Ma}$, and quartzite from the Haerhada Formation formed from 445 to $480 \mathrm{Ma}$. Actually, the metaandesite sample was collected at a location very close to that of samples WD03-1/2 and WD04-2 in this study, and the meta-andesite might be meta-basalt with age similar to WD04-2 as there are no available geochemical data in their paper. Zircons in the quartzite should be detrital, only indicating the lower age limit of sedimentation. Liu et al. [22] 

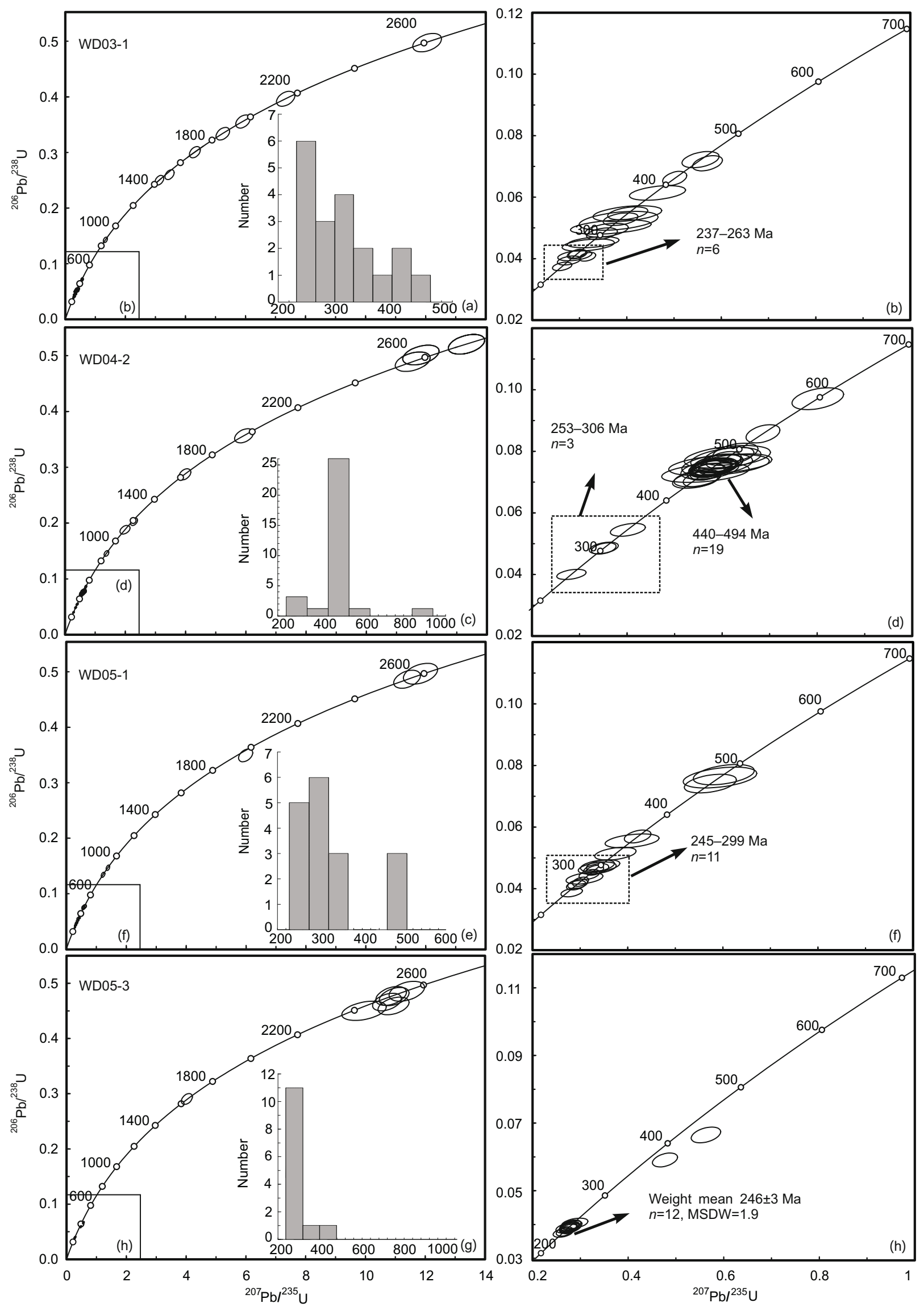

Figure 6 Concordia plots of zircon U-Pb ages for meta-basic volcanics in the Ondor Sum Group. 
reported the Late Ordovician adakite-like dacite aged 458 Ma present in the Ondor Sum Group at Tulinkai, and in the same area, Jian et al. [21] obtained SHRIMP zircon ages of 497-477 Ma from meta-gabbro and plagiogranite. However, as shown in Figure 1(c), these rocks are all located along the southern edge of the Ondor Sum Group and ought to be the materials from the Early Paleozoic magmatic arc.

The present study shows that zircons from meta-basic volcanics in the Ondor Sum Group are derived from complicated sources and yield a broad age range from late Archean to early Mesozoic. Most zircon grains have oscillatory growth zoning, similar to the zircons from acidic intrusives. It is supposed that these zircons may be captured by basic magma from the country rocks during uplifting, and cannot represent the primary zircons in the basic rocks. Presumably, zircons with ages between 1600 and $2734 \mathrm{Ma}$ may be from the North China Craton [34], and zircons with ages between 700 and $1000 \mathrm{Ma}$ are probably associated with the Neoproterozoic magmatism in the east section of Central Asian Orogen [35]. The abundant zircons aging between 300 and 494 Ma should be originated from the adjacent Paleozoic intermediate-acidic magmatic rocks of arc type [7,20-22], and zircons with younger ages from 246 to $261 \mathrm{Ma}$ originated from the neighbouring Permian granites $[36,37]$. Therefore, the protolith of the meta-basic volcanics in the Ondor Sum group can be well constrained to be formed from Late Permian to Early Triassic or latter. The meta-basic volcanics have similar geochemical characteristics to E-MORB with an evolution toward OIB, which may represent a limited intracontinental ocean basin. This tectonic setting is consistent with the presence of the large amount of zircons originated from continental rocks. Although the study samples are all collected from the southern zone of the Ondor Sum Group, Chen et al. [19] obtained the same zircon age spectra from the blueschist in the northern zone, suggesting the Ondor Sum Group may have the similar age and tectonic setting in both the southern and northern zones.

Many studies suggest that the Paleo-Asian Ocean may have been closed in Devonian, a neritic sedimentary sequence developed in Carboniferous, and an extensional tectonic environment was prevailed during the Early Permian in the study area. This extensional environment is supported by (i) a large amount of Early Permian alkaline rocks (290-270 Ma) distributed from Erenhot to East Ujimqin Banner [36,37]; (ii) numerous high potassium calc-alkaline and alkaline granites developing in the northern margin of North China Craton [38,39]; and (iii) bimodal volcanics present in the Early Permian Dashizhai Formation, which display a widely planar spatial distribution $[40,41]$. Due to the regional extension beginning in the Early Permian, a sea basin might be formed in the central Inner Mongolia in the Middle Permian, in which developed the neritic sedimentary sequence of the Zhesi Formation, and continuous extension might result in the formation of a limited ocean basin, in which developed the large amount of basic volcanics and ferruginous siliceous rocks, i.e. the Ondor Sum Group. The limited ocean basin was finally closed in Mesozoic, accompanied with a regional metamorphism locally with blueschist appearance and granitic intrusions [42,43].

This work was supported by the National Natural Science Foundation of China (40902021), the National Basic Research Program of China (2013CB429801) and the China Survey of Geology (1212010911005). We sincerely thank Professor Su Li at the State Key Laboratory of Geological Processes and Mineral Resources in China University of Geosciences (Beijing) for her help during the LA-ICP-MS zircon U-Pb dating. Two anonymous reviewers are much appreciated for their critical comments on the manuscript.

1 Tang K D. Tectonic development of Paleozoic fold belts at the northern margin of the northern margin of the Sino-Korean craton. Tectonics, 1990, 9: 249-260

2 Shao J A. Crust Evolution in the Middle Part of the Northern Margin of Sino-Korean Plate (in Chinese). Beijing: Peking University Press, 1991. 1-135

$3 \mathrm{Xu} \mathrm{B}$, Chen B. Framework and evolution of the middle Paleozoic orogenic belt between Siberian and North China Plates in northern Inner Mongolia. Sci Chin Ser D-Earth Sci, 1997, 40: 463-469

$4 \mathrm{Xu} \mathrm{B}$, Charvet J, Zhang F Q. Primary study on petrology and geochronology of the blueschist in Sunidzuoqi, northern Inner Mongolia (in Chinese). Chin J Geol, 2001, 36: 424-434

$5 \mathrm{Xu} \mathrm{B}$, Charvet J, Chen Y, et al. Middle Paleozoic convergent orogenic belts in western Inner Mongolia (China): Framework, kinematics, geochronology and implications for tectonic evolution of the Central Asian Orogenic Belt. Gondwana Res, 2013, 23: 1342-1364

6 Sengör A M C, Natal' B A. Paleotectonics of Asia: Fragments of a synthesis. In: Yin A, Harrison T M, eds. The Tectonic Evolution of Asia. Cambridge: Cambridge University Press, 1996. 486-641

7 Chen B, Jahn B M, Wilde S, et al. Two contrasting Paleozoic magmatic belts in northern Inner Mongolia, China: Petrogenesis and tectonic implications. Tectonophysics, 2000, 328: 157-182

8 Xiao W J, Windley B F, Hao J, et al. Accretion leading to collision and the Permian Solonker suture, Inner Mongolia, China: Termination of the central Asian orogenic belt. Tectonics, 2003, 22: 10691088

9 Windley B F, Alexelew D, Xiao W J, et al. Tectonic models for accretion of the Central Asian Orogenic Belt. J Geol Soc Lond, 2007, 164: 31-47

10 Wu F Y, Zhao G C, Sun D Y, et al. The Hulan Group: Its role in the evolution of the Central Asian Orogenic Belt of NE China. J Asian Earth Sci, 2007, 30: 542-556

11 Shang Q H. Occurrences of Permian radiolarians in central and eastern Nei Mongol (Inner Mongolia) and their geological significance to the Northern China Orogen. Chin Sci Bull, 2004, 49: 2613-2619

12 Li D P, Chen Y L, Wang Z, et al. Paleozoic sedimentary record of the Xing-Meng Orogenic Belt, Inner Mongolia: Implications for the provenances and tectonic evolution of the Central Asian Orogenic Belt. Chin Sci Bull, 2012, 57: 776-785

13 Zhou J B, Wilde S A. The crustal accretion history and tectonic evolution of the NE China segment of the Central Asian Orogenic Belt. Gondwana Res, 2013, 23: 1365-1377

14 Meng E, Xu W L, Pei F P, et al. Permian bimodal volcanism in the Zhangguangcai Range of eastern Heilongjiang Province, NE China: Zircon U-Pb-Hf isotopes and geochemical evidence. J Asian Earth Sci, 2011, 41: 119-132

$15 \mathrm{Hu}$ X, Xu C S, Niu S Y. Evolution of the Early Paleozoic Continental Margin in Northern Margin of the North China Platform (in Chinese). Beijing: Peking University Press, 1990. 6-23

$16 \mathrm{Xu} \mathrm{B}$, Chen B, Bai Z Q, et al. The age and tectonic significance of 
Ferroan Metamorphic Series in the middle segment of the northern margin of the North China plate (in Chinese). Geol Rev, 1994, 40: 307-331

17 Zhang C, Wu T R. Sm-Nd, Rb-Sr isotopic isochron of metamorphic volcanic rocks of Ondor Sum group, Inner Mongolia (in Chinese). Chin J Geol, 1998, 33: 25-30

18 Shi Y R, Liu D Y, Zhang Q, et al. SHRIMP U-Pb zircon dating of Triassic A-type granites in Sonid Zuoqi, central Inner Mongolia, China and its tectonic implications (in Chinese). Geol Bull Chin, 2007, 26: 183-189

19 Chen B, Ma X H, Liu A K, et al. Zircon U-Pb ages of the Xilin Hot metamorphic complex and blueschist and implications for tectonic evolution of the Solonker suture (in Chinese). Acta Petrol Sin, 2009, 25: 3123-3129

20 Li C D, Zhao L G, Wang H C, et al. LA-MC-ICP MS U-Pb geochronology of zircons from the Wenduermiao Group and its tectonic significance (in Chinese). Acta Petrol Sin, 2012, 28: 3705-3714

21 Jian P, Liu D Y, Kroner A, et al. Time scale of an early to midPaleozoic orogenic cycle of the long-lived Central Asian Orogenic Belt, Inner Mongolia of China: Implications for continental growth. Lithos, 2008, 101: 233-259

22 Liu D Y, Jian P, Zhang Q, et al. SHRIMP Dating of Adakites in the Tulinkai Ophiolite, Inner Mongolia: Evidence for the Early Paleozoic Subduction (in Chinese). Acta Geol Sin, 2003, 77: 317-327

23 Tang K D, Yan Z J, Zhang R P, et al. On Wentermiao Group and its tectonic significance (in Chinese). Contrib Proj Plate Tect Northern Chin, 1983, 1: 186-208

24 Winchester J A, Floyd P A. Geochemical magma type discrimination: application to altered and metamorphosed igneous rocks. Earth Planet Sci Lett 1976, 45: 326-336

25 Glassley W. Geochemistry and tectonics of the Crescent Volcanic rocks, Olympia Peninsula, Washington. Geol Soc America Bull, 1974, 85: 785-794

$26 \mathrm{Xu} \mathrm{B.} \mathrm{Sedimentary} \mathrm{environment} \mathrm{and} \mathrm{tectonic} \mathrm{significance} \mathrm{of} \mathrm{the}$ north belt of the Ondor Sum group in Inner Mongolia (in Chinese). Chin J Geol, 1998, 33: 406-411

27 Wood D A. The application of a Th-Hf-Ta diagram to problems of tectono-magmatic classification and to establishing the nature of crustal contamination of basaltic lavas of the British Tertiary volcanic province. Earth Planet Sci Lett, 1980, 42: 77-97

28 Pearce J A, Cann J R. Tectonic setting of basic volcanic rocks determined using trace element analyses. Earth Planet Sci Lett, 1973, 19: 290-547

29 Sun S S, McDonough W F. Chemical and isotopic systematic oceanic basalt: Implications for mantle composition and process In: Saundern A D, Norry M J, eds. Magmatism in the Ocean Basins. Geol Soc Spec Publ, 1989, 42: 313-345

30 Anderson T. Correction of common lead in $\mathrm{U}-\mathrm{Pb}$ analyses that do not report ${ }^{204} \mathrm{~Pb}$. Chem Geol, 2002, 192: 59-79

31 Ludwig K R. Using Isoplot/EX, version 2.49. A Geochronological Toolkit for Microsoft Excel. Berkeley Geochronol Center Spec Publ, 2001, 1-55

32 De J K, Xiao W J, Windley B F, et al. Ordovician ${ }^{40} \mathrm{Ar} /{ }^{39} \mathrm{Ar}$ phengite ages from the blueschist-facies Ondor Sum subduction-accretion complex (Inner Mongolia) and implications for the Early Paleozoic history of continental blocks in China and adjacent areas. Am J Sci, 2006, 306: 799-845

33 Tang K D. Tectonic Evolution and Minerogenetic Regularities of the Fold Belt along the Northern Margins of Sino-Korean Plate (in Chinese). Beijing: Peking University Press, 1992. 277-278

34 Zhao G C, Cawood P A, Wilde S A, et al. Metamorphism of basement rocks in the central zone of the North China craton: Implications for Paleoproterozoic tectonic evolution. Precambrian Res, 2000, 103: 55-88

35 Zhou J B, Simon A W, Zhang X Z, et al. Detrital zircons from Phanerozoic rocks of the Songliao Block, NE China: Evidence and tectonic implications. J Asian Earth Sci, 2012, 47: 21-34

36 Hong D W, Huang H Z, Xiao Y J, et al. The Permian alkaline granites in Central Inner Mongolia and their geodynamic significance (in Chinese). Acta Geol Sin, 1994, 68: 219-230

37 Shi G H, Miao L C, Zhang F Q, et al. The age and its regional tectonic implication of the Xilinhot A-type granites, Inner Mongolia. Chin Sci Bull, 2004, 49: 384-389

38 Zhang S H, Zhao Y, Song B, et al. Contrasting late Carboniferous and late Permian-Middle Triassic intrusive suites from the northern margin of the North China Craton. Geol Soc Am Bull, 2009, 121: 181-200

39 Luo H L, Wu T R, Li Y. Geochemistry and SHRIMP dating of the Kebu massif from Wulatezhongqi, Inner Mongolia: Evidence for the Early Permian underplating beneath the North China Craton (in Chinese). Acta Petrol Sin, 2007, 23: 755-766

40 Zhang X H, Zhang H F, Tang Y J, et al. Geochemistry of Permian bimodal volcanic rocks from central Inner Mongolia, North China: Implication for tectonic setting and Phanerozoic continental growth in Central Asian Orogenic Belt. Chem Geol, 2008, 249: 262-281

41 Zhu Y F, Sun S H, Gu L B, et al. Permian volcanism in the Mongolian orogenic zone, Northeast China: Geochemistry, magma sources and petrogenesis. Geol Mag, 2001, 138: 101-115

42 Li Y L, Zhou H W, Zhong Z Q, et al. Collision processes of North China and Siberian Plates: Evidence from LA-ICP-MS Zircon U-Pb Age on deformed granite in Xar Moron Suture Zone (in Chinese). Earth Sci, 2009, 34: 1-8

43 Li J Y, Gao L M, Sun G H, et al. Shuangjingzi middle Triassic syncollisional crust-derived granite in the east Inner Mongolia and its constraint on the timing of collision between Siberian and Sino-Korean Paleo-plates (in Chinese). Acta Petrol Sin, 2007, 23: 565-582

Open Access This article is distributed under the terms of the Creative Commons Attribution License which permits any use, distribution, and reproduction in any medium, provided the original author(s) and source are credited. 